\author{
BeAta StelmaCH-FitA \\ Uniwersytet Pedagogiczny w Krakowie, Polska \\ Pedagogical University of Krakow, Poland
}

\title{
Nowe zintegrowane planowanie w kontekście kształtowania i rozwoju terenów przemysłowych i usługowych w regionach metropolitalnych
}

\author{
New Integrated Planning in the Context of Shaping and Development \\ of Industrial and Service Areas in Metropolitan Regions
}

\begin{abstract}
Streszczenie: Artykuł dotyczy badań jakościowych, regionalnych. Jest głosem w dyskursie na temat poszukiwanego „modelu zintegrowanego planowania” (społeczno-gospodarczego i przestrzennego) w Polsce, który byłby spójny z prawem Unii Europejskiej i dawał możliwość wykorzystywania potencjałów rozwojowych regionu metropolitalnego. Badania regionalne są prowadzone przez autorkę od 2012 roku, a wspólnie z zespołem badawczym w latach 2016-2017. Jako studium przypadku zaprezentowano działania podejmowane w Pomorskim Biurze Planowania Regionalnego w Gdańsku. Między innymi opisano metody określania zasad zagospodarowania przestrzennego wykorzystane w Planie zagospodarowania przestrzennego Obszaru Metropolitalnego Gdańsk-Gdynia-Sopot 2030 oraz metody delimitacji strategicznych obszarów rozwoju funkcji metropolitalnych. Doceniając również inne obserwowane działania w samorządach wojewódzkich, integrujące planowanie przestrzenne z polityką rozwojową, autorka dokonała próby identyfikacji mechanizmów zintegrowanego planowania, które mogą mieć wpływ na kształtowanie i rozwój terenów przemysłowo-usługowych. Jednak w opinii autorki bez zmiany systemu prawnego te wszystkie opisane działania będą miały niewielki wpływ na efektywne, właściwe wykorzystanie gruntów. Jako konkluzję autorka zaprezentowała model planowania przestrzennego w zintegrowanym systemie polityki rozwoju kraju - do dalszych dyskusji.
\end{abstract}

\begin{abstract}
The article concerns qualitative and regional research. It is a voice in the discourse in search of the best "model of integrated planning" (socio-economic and spatial) in Poland, which would be consistent with European Union law and give the fullest opportunity to use the development potential of the metropolitan region. Regional research has been carried out by the author since 2012 and together with the research team in 2016-2017. As part of the case study, the activities undertaken at the Pomeranian Regional Planning Office in Gdańsk are presented. Among others, the methods for determining the spatial development principles used in the "Spatial Development Plan for the Gdańsk-Gdynia-Sopot Metropolitan Area 2030" and methods for delimitation of strategic areas for the development of metropolitan functions are described. Also appreciating other observed activities in voivodeship self-governments, integrating spatial planning with development policy, the author has made an attempt to identify the mechanisms of integrated planning that may affect the shaping and development of industrial and service areas. However, in the author's opinion, without changing the legal system, all these activities will have little impact on effective, proper use of land,
\end{abstract}


including for economic (industrial and service) activities. As the conclusion of the research and recommendations, the author presented the "Model of spatial planning in the integrated system of the country's development policy" for further discussions.

Słowa kluczowe: informacja o istniejącym i planowanym zagospodarowaniu przestrzennym; obszary metropolitalne; przedsiębiorcy; rozwój społeczno-gospodarczy i przestrzenny; samorząd terytorialny; teren w transformacji; zintegrowane planowanie

Keywords: entrepreneurs; information about existing and planned land use; integrated planning; land in transformation; local government; metropolitan spaces; spatial and social-economic development

Otrzymano: 20 czerwca 2019

Received: 20 June 2019

Zaakceptowano: 24 lipca 2019

Accepted: 24 July 2019

Sugerowana cytacja / Suggested citation:

Stelmach-Fita, B. (2019). Nowe zintegrowane planowanie w kontekście kształtowania i rozwoju terenów przemysłowych i usługowych w regionach metropolitalnych. Prace Komisji Geografii Przemysłu Polskiego Towarzystwa Geograficznego, 33(4). 260-282. doi: 10.24917/20801653.334.16

\section{WSTĘP}

Profesor H. Izdebski (2010: 15), współtwórca reformy samorządowej, podkreślał, że właściwe zarządzanie obszarami funkcjonalnymi dużych aglomeracji miejskich należy do największych i najtrudniejszych wyzwań, jakie stoją przed polską administracją publiczną. Niestety żadna z dotychczasowych reform administracyjnych jeszcze się z nim nie zmierzyła (Janas, Jarczewski, 2017). O złożoności zagadnienia świadczyć może również fakt, że wypracowanie optymalnego rozwiązania w celu sprawnego i efektywnego zarządzania miejskimi obszarami funkcjonalnymi (MOF) jest już od kilku dekad przedmiotem nieustającej debaty w całej Europie, a nawet poza naszym kontynentem (Kaczmarek, 2005; Kaczmarek, Mikuła, 2007; Lackowska, 2009).

W Polsce podejmowane są istotne inicjatywy zmierzające do rozwiązywania problemów MOF, wspierania samorządów oraz władz regionalnych i krajowych w procesie tego zarządzania, począwszy od przyjęcia przez rząd w 2015 roku Krajowej Polityki Miejskiej 2023, powołania do życia Obserwatorium Polityki Miejskiej, a wcześniej Krajowego Obserwatorium Terytorialnego (a w jego ramach regionalnych obserwatoriów terytorialnych - ROT) czy opracowywania wielu analiz oraz raportów i zamieszczania ich na stronach internetowych ww. jednostek. Rozpoczętych w Polsce reform jednak nie zakończono. W prowadzonym dyskursie na temat prób integrowania planowania społeczno-gospodarczego z przestrzennym nadal do końca nie wiadomo, jak to nowe zintegrowane planowanie miałoby wyglądać. Czy ma to być pionowa integracja, czy pozioma, czy w sferze normatywnej, czy operacyjnej (koordynacji czasowej, przestrzennej)?

Z kolei badacze z innych krajów informują o potrzebie szkoleń w zakresie „edukacji, uczenia się i przywództwa w kierunku nowej dyscypliny metropolitalnej - architektura metropolii", w tym zwracając szczególną uwagę na kwestie hydrografii (Contin, 2019; Contin, Sanna, 2019).

Pierwsza część artykułu stanowi wprowadzenie do zintegrowanego planowania, a druga zawiera najistotniejsze wnioski z wyników badań regionalnych, realizowanych przez autorkę w 2012 roku (dolnośląskie) oraz z zespołem naukowym w latach 
2016-2017 (małopolskie, wielkopolskie oraz ankieta skierowana do wszystkich urzędów marszałkowskich) i kontynuowanych przez autorkę w 2018 roku (pomorskie).

Zdaniem T. Markowskiego trzeba jak najszybciej przystąpić do zbudowania użytecznych metod prognostycznych, nie tylko na poziomie lokalnym, ale także prognoz współzależnych, adekwatnych do zakresu kompetencji terytorialnej i rządowej. Globalizacja i współczesny rozwój wymuszają nowe podejście do planowania rozwoju. Wymienianymi postulatami są potrzeby zintegrowanego podejścia oraz uwzględnianie w planowaniu i w jego ustaleniach wysokiej elastyczności i zmienności współczesnych procesów gospodarczych. (Markowski, 2017). Przy czym J. Zaucha (2012) zauważa, że Markowski (2011) „koncepcję rozumienia roli i sposobu funkcjonowania spójności terytorialnej sprowadza do potrzeby zintegrowania programowania rozwoju obejmującego zagadnienia społeczne, gospodarcze i przestrzenne, w którym planowanie przestrzenne jest instrumentem koordynacji terytorialnego wymiaru i oddziaływania funkcji (aktywności)".

Głównym celem całościowych badań jest poszukiwanie nowych sposobów strategicznego programowania rozwoju oraz potrzebnych do tego wiarygodnych, kompletnych informacji i danych o zjawiskach społeczno-gospodarczych i przestrzennych, w tym porównywalnych dla wszystkich województw, które są potrzebne wielu użytkownikom m.in. do wspierania i monitorowania polityki rozwoju, a zwłaszcza polityki przestrzennej, która jest integralnym elementem polityki rozwoju.

Natomiast w artykule zaprezentowano cząstkowe wyniki badań dotyczące próby identyfikacji mechanizmów zintegrowanego planowania, które mogą mieć wpływ na kształtowanie i rozwój terenów przemysłowo-usługowych w regionach metropolitalnych. Sprecyzowano następujące pytania badawcze:

1. Jakie mechanizmy zintegrowanego planowania, które mogą mieć wpływ na kształtowanie i rozwój terenów przeznaczonych pod działalność przemysłową i usługową, są wdrażane na poziomie wojewódzkim?

2. Jakie są bariery we wdrażaniu tego typu mechanizmów?

3. Czy poziom regionalny (wojewódzki) ma największy potencjał do wdrażania mechanizmów planowania zintegrowanego?

Materiały z przywołanych w artykule wywiadów indywidualnych są dostępne $\mathrm{u}$ autorki artykułu.

\section{ZINTEGROWANE PLANOWANIE - WPROWADZENIE}

Porównując współczesne sposoby prowadzenia polityki ekonomicznej w krajach o gospodarce rynkowej, stwierdzić można występowanie wielu odmienności. Inaczej przedstawiają się funkcje polityki ekonomicznej w modelu amerykańskim, inaczej w japońskim, francuskim, hiszpańskim czy włoskim. Szczególny typ instytucji polityki ekonomicznej charakteryzuje kraje, których rządy deklarują kierowanie się zasadami tzw. społecznej gospodarki rynkowej (Niemcy, Austria). Istotną rolę odgrywa w nich polityka społeczna osłaniająca słabsze warstwy i jednostki. W Niemczech i we Francji przywiązuje się również wielką wagę do kształtowania przez państwo ładu przestrzennego przez aktywne oddziaływanie na procesy zagospodarowania i rozwoju regionów. Ważnymi stają się polityki publiczne. Zjawisko urbanizacji nadal stanowi problem, zwłaszcza na obszarach wiejskich, które zmieniają swoje funkcje, tracą tereny otwarte na rzecz rozwoju mieszkalnictwa i usług. 
Poszczególne działania w procesie zarządzania, takie jak: planowanie, organizowanie, motywowanie (kierowanie) i kontrolowanie, można w przybliżeniu utożsamiać z szeroko rozumianymi etapami planowania, odpowiednio: diagnozy, projektowania, wdrażania i ewaluacji czy monitoringu (zmian w zagospodarowaniu przestrzennym). Na potrzeby badań przyjęto założenie, że zintegrowane planowanie, zarządzanie przestrzenią jest szczególnym przypadkiem zarządzania, a nie czynnością podejmowaną w trakcie zarządzania.

Zintegrowane planowanie strategiczne nie jest pojedynczą koncepcją, procedurą czy narzędziem. Jest to zbiór koncepcji, procedur i narzędzi, które muszą być dopasowane do specyficznych sytuacji i obszarów, jeżeli mają być osiągnięte pożądane wyniki. Jest ono szerszym podejściem niż tradycyjne planowanie. Rozważa najlepsze wykorzystanie terenu i dostarczenie większego wsparcia dla polityk i innych organizacji promujących zmiany na danym terytorium i zarządzających nimi. Zakłada się, że to zintegrowane planowanie przyczyni się do lepszej organizacji przestrzennej w Europie oraz do znalezienia rozwiązań problemów, które wykraczają poza ramy krajowe. Jego celem jest stworzenie poczucia wspólnej tożsamości, w stosunkach wschód-zachód i północ-południe, a przede wszystkim planowanie na ludzką skalę i dotyczące rzeczywistych potrzeb.

Efekty uboczne i wyniki procesów planowania muszą być monitorowane w celu zintegrowania nowych wyników, trwających różnych procesów planowania. Te wszystkie nakłady danych stale wpływają na wszystkich udziałowców przestrzeni, (w tym na decyzje przedsiębiorców o nowych lokalizacjach przemysłu i usług), a następnie również na rezultat planowania. Istotne jest koordynowanie i równoważenie różnych interesów. Z tych powodów nie wykonuje ono operacji znormalizowanych i rutynowych, ale zawsze jest procesem złożonym, unikatowym, twórczym, który nie wiąże się tylko z zadaniami technicznymi i określonymi metodami, ale również w dużej mierze z kreatywnością. Proces planowania nie jest liniowy, ale ciągły, co oznacza, że ciągle pobiera (wprowadzane w tym rozwoju) nowe dane. Można powiedzieć, że cykl planowania nigdy nie kończy się i że po zakończeniu jednego cyklu następny już został uruchomiony.

Rycina 1. Cykl planistyczny nigdy się nie kończy

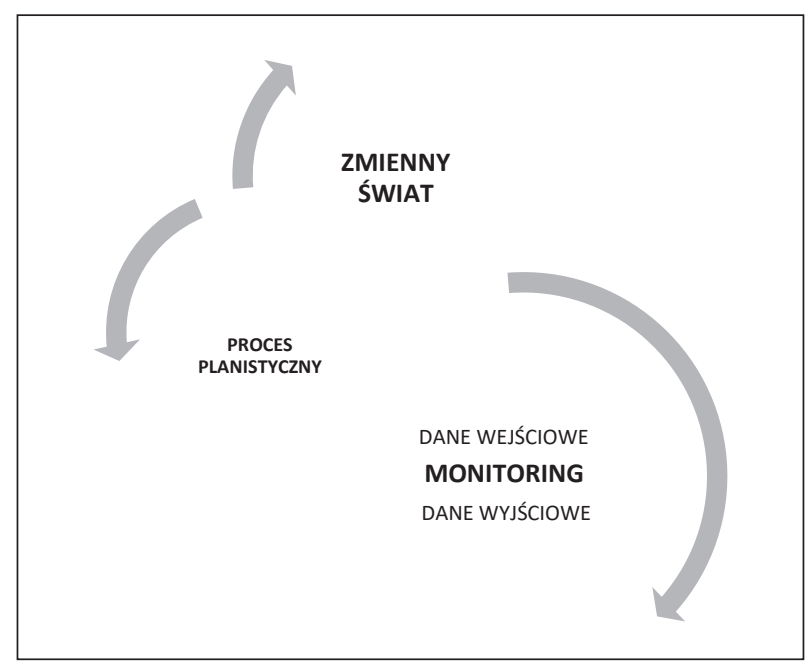

Źródło: opracowanie własne 
W wymiarze transgranicznym taki monitoring jest tym bardziej potrzebny. Istotne jest zapewnienie wsparcia metodologicznego oraz wiedzy terytorialnej wspierającej spójność terytorialną (rola ESPON ${ }^{1}$ ) oraz gromadzenie danych regionalnych i miejskich mających istotne znaczenie dla rozwoju terytorialnego. W programie ESPON 2013 wykorzystano typologię regionów, której poświęca się szczególną uwagę w trakcie dążenia do spójności zbieranych wszelkiego rodzaju wskaźników, danych statystycznych spójnych z Eurostatem ${ }^{2}$. Ustanowiona typologia wynika z typów terytoriów wymienionych w traktacie lizbońskim $\S 174$ (Agenda..., 2019). Od 2010 roku obowiązuje typologia regionalna: 1) regiony miejsko-wiejskie, 2) regiony metropolitalne, 3) regiony przygraniczne, 4) regiony wysp; 5) regiony słabo zaludnione, 6) regiony najbardziej oddalone; 7) regiony górskie; 8) regiony przybrzeżne; 9) regiony w przemianach przemysłowych (A1 - z gałęziami tracącymi na znaczeniu, A2 - z gałęziami przemysłu zyskującymi na znaczeniu, A3 - z wewnętrznymi zmianami strukturalnymi w przemyśle, B - pozostałe obszary nieobjęte typologią).

Najważniejszą polityką europejską dotyczącą tematyki miast, opracowaną i przyjętą w ostatnich latach, jest niewątpliwie Agenda miejska UE, ratyfikowana przez kraje członkowskie w maju 2015 roku (Vergas-Tetmajer, 2017: 143), która ustanawia partnerstwo na rzecz zrównoważonego wykorzystania przestrzeni i rozwiązań opartych na środowisku naturalnym. Dzięki temu miasta europejskie zyskują możliwość lepszego dostosowania swoich polityk do unijnego prawodawstwa oraz wpływ na jego przyszły rozwój, lepszy dostęp do finansowania oraz lepszy dostęp do wiedzy dotyczącej problematyki miejskiej. Do 12 priorytetów powołano 12 zespołów tematycznych, w ramach których przedstawiciele miast i rządów państw europejskich pracują wspólnie nad formułowaniem propozycji ulepszania istniejących polityk i zmian legislacyjnych. Celem partnerstwa jest promowanie i wzmacnianie zrównoważonego wykorzystania zasobów naturalnych, w tym zasobów przestrzeni (grunty), w środowisku miejskim. Trwają prace nad propozycjami zmian praktycznych metodologii i rekomendacji w takich dziedzinach, jak: zajmowanie gruntów, wykorzystanie terenów nieużytkowanych i poprzemysłowych, miejskie obszary funkcjonalne. Działanie 2, „Wytyczne w zakresie wspierania i finansowania regeneracji terenów poprzemysłowych", zawiera przewodnik finansowy - dostarczanie miastom aktualnych informacji na temat sposobów finansowania na szczeblu UE oraz stymulowania inwestycji prywatnych na rzecz przebudowy terenów zdegradowanych (brown fields), zachęcanie miast do wykorzystywania terenów poprzemysłowych zamiast zajmowania nowych terenów. Zasady takiego efektywnego sposobu wykorzystywania obecnych zasobów terenów wprowadzone są w ustaleniach dokumentów planistycznych w województwie pomorskim.

Polskiemu systemowi planowania przestrzennego zarzuca się m.in. oferowanie uzupełnienia dotychczasowych regulacji w miejsce ustanowienia spójnego, hierarchicznego, czytelnego prawa planowania przestrzennego na miarę wyzwań XXI wieku. Odnośnie do zagospodarowywania terenów w Polsce na podstawie decyzji o warunkach zabudowy i zagospodarowania terenu stwierdzono: „Dopóki istnieją alternatywne sposoby ustalania warunków zabudowy (na podstawie planu lub decyzji), sytuacja planistyczna w poszczególnych miastach będzie kształtowana nie pod wpływem

${ }^{1}$ ESPON - Europejska Sieć Obserwacyjna Rozwoju Terytorialnego i Spójności Terytorialnej.

2 Eurostat - Urząd Statystyczny Unii Europejskiej, w tym klasyfikacje działalności gospodarczej spójne z HILUCS. 
zobiektywizowanych potrzeb, lecz pod wpływem interesów poszczególnych inwestorów" (Kolipiński, 2012: 15).

W krajach UE funkcjonuje po kilka typów planów, ponadto przynajmniej jeden z nich posiada funkcję regulacyjną. W Holandii wszystkie instrumenty polityki przestrzennej udało się ująć w jednym modelu informatycznym, a dzięki temu ustawa zawiera mało przepisów. W Hiszpanii funkcjonuje dziewięć typów planów, w tym takie mechanizmy integrujące cały system planowania, jak stabilny podział gruntów na trzy klasy i plan regulacyjny na poziomie lokalnym.

Wytyczne do zintegrowanego planowania przygotowane przez środowisko urbanistów zmierzają w kierunku ustanowienia takiego typu planu. Rozwinięcie tych kwestii nastąpi w końcowej części artykułu. Wszystkie te problemy mają swoje przełożenie na brak efektywnego wykorzystania gruntów, w tym terenów pod działalność przemysłowo-usługową.

„Esencją planowania przestrzennego, zwłaszcza w wymiarze ponadlokalnym, jest poszukiwanie potencjalnych lub faktycznych związków funkcjonalnych obszarów i kształtowanie na ich podstawie logicznych, efektywnych i zrównoważonych struktur rozwoju. Pomimo braku podstaw prawnych dla tak pojmowanego planowania część województw nigdy nie porzuciła tej ścieżki myślenia o przestrzeni regionalnej i opracowywała dokumenty o charakterze miękkim i nieformalnym" (Belof, 2013: 148-150). W opracowaniach tego typu wyróżnić można plany dla obszarów wrażliwych ekologicznie i krajobrazowo, jak również koncepcje zagospodarowania pasm korytarzy transportowych lub obszarów charakteryzujących się intensywnym rozwojem przemysłu.

Jeszcze inną kwestią jest nurt projektowania urbanistycznego przenikający się z planowaniem przestrzennym i potrzeba usystematyzowania oraz przedyskutowania pojawiających się zupełnie nowych definicji pojęć związanych z obszarami metropolitalnymi, które również mogą mieć wpływ na kształtowanie wielofunkcyjnych obszarów metropolitalnych (różnego rodzaju usługi). K. Guranowska-Gruszecka, M. Łaskarzewska (2018: 10) prowadzą wielostronne studia miejskie, w tym przywołują innych badaczy, wśród których nie sposób nie wspomnieć Z. Zuziaka (2018). Autorki na początku badań ustaliły definicje „węzłów miasta”, „miejskości”, „węzłów miejskości”3 oraz „przestrzennej struktury metropolitalnej”.

\section{ZINTEGROWANE PLANOWANIE - KONTEKST INFRASTRUKTURY}

Badacze widzą związek nowego podejścia do strategicznego planowania przestrzennego z powstawaniem Europejskiej Infrastruktury Informacji Przestrzennej (IIP).

Jednym z tematów jest „zagospodarowanie przestrzenne”, w ramach którego w założeniu mają być udostępniane zbiory danych dotyczące istniejącego (różnych źródeł

\footnotetext{
${ }^{3}$ Węzły miejskości (WM) to wielowarstwowe formy zagospodarowania przestrzennego odpowiadające koncentracjom funkcji, czyli aktywnościom związanym z miejskością. Przykładem węzłów miejskości są: centra miast, centra dzielnicowe i osiedlowe, a także inne koncentracje funkcjonalno-przestrzenne, np. miejsca czy obszary wokół przystanków transportu zbiorowego, gdzie intensywność zabudowy rośnie odpowiednio do dostępności komunikacyjnej centralnego miejsca danego skupiska i gdzie wykształcił się lub pojawia się pewien typ przestrzeni urbanistycznej, który można uznać za przestrzeń publiczną. W przypadku układów miejskich mających silny związek z gospodarką opartą na wiedzy (KE - knowledge economy) istotną rolę odgrywają węzły miejskości odpowiadające kampusom uniwersyteckim, parkom nauki, parkom technologicznym itp.
} 
danych) i planowanego zagospodarowania przestrzennego (wynikającego z dokumentów planistycznych). Jeżeli w danym kraju funkcjonują regulacyjne plany typu strefowego, to udostępniane mają być również porównywalne strefy polityki przestrzennej w jednolitej klasyfikacji kategorii zagospodarowania przestrzennego HILUCS ${ }^{4}$, umożliwiając przez to monitoring zmian w dowolnych odstępach czasu i odpowiednio szybkie reagowanie na te zmiany. Ustanowiona infrastruktura jest pewnego rodzaju integratorem wszystkich danych przestrzennych w Europie, a zbiory danych „zagospodarowania przestrzennego” / „Land use” mogą stać się jednym z podstawowych mechanizmów zintegrowanego planowania. Już na podstawowym poziomie można zauważyć, że na sześć kategorii aż trzy dotyczą przemysłu: 1) podstawowa produkcja, 2) drugorzędna produkcja, 3) trzeciorzędna produkcja, 4) sieci transportowe, narzędzia logistyczne, 5) mieszkaniowe użytkowanie, 6) inne użytkowanie.

Przez to, że w Polsce nie ma planu typu strefowego, z jednolitą, stabilną klasyfikacją stref polityki przestrzennej, obecnie nie wykorzystuje się w pełni możliwości tej infrastruktury.

Odnośnie do obowiązku krajów UE udostępniania w IIP omawianych zbiorów danych, w rozporządzeniu (UE) nr 1253/2013 z dnia 21 października 2013 r. zmieniającym rozporządzenie (UE) nr 1089/2010 w sprawie wykonania dyrektywy 2007/2/WE5 w zakresie interoperacyjności zbiorów i usług danych przestrzennych zapisano: „przez plan zagospodarowania przestrzennego rozumie się: zestaw dokumentów, w których wskazano kierunek strategiczny rozwoju danego obszaru geograficznego, przedstawiono politykę, priorytety, programy i podział gruntów, służące realizacji kierunku strategicznego i wpływające na rozkład ludności oraz działalności w różnej skali przestrzennej. Plan zagospodarowania przestrzennego może zostać opracowany na potrzeby planowania miejskiego, planowania regionalnego, planowania w zakresie ochrony środowiska, planowania krajobrazu, krajowych planów zagospodarowania przestrzennego lub planowania przestrzennego na szczeblu UE”.

W projekcie Kodeksu urbanistyczno-budowlanego (Kodeks..., 2016) postanowiono, że minimalny zakres monitoringu na każdym poziomie zarządzania ma mieć ciągły charakter i być:

- podstawą podejmowania rozstrzygnięć przestrzennych,

- obowiązkiem organów prowadzących politykę przestrzenną,

- wykorzystywany z zewnętrznych źródeł danych (IIP, Zintegrowany System Informacji o Nieruchomościach, satelitarna obserwacja Ziemi, statystyka publiczna).

Monitorowanie stref przeznaczonych do urbanizacji w studium uwarunkowań i kierunków zagospodarowania przestrzennego gminy powinno charakteryzować:

- zgodność z programem rozwoju przestrzennego gminy,

- obszar zurbanizowany oraz (ewentualnie) obszar nowej urbanizacji,

- podział gminy na strefy funkcjonalne spójne z klasyfikacją HILUCS,

- standardy urbanistyczne,

- podstawowe parametry zagospodarowania terenu,

- plan wykonania studium - harmonogram realizacji polityki przestrzennej.

Zdaniem autorki artykułu wytyczne Kodeksu urbanistycznego powinny być wdrażane etapowo.

${ }^{4}$ Hierarchical INSPIRE Land Use Classification System (HILUCS) (Specyfikacja danych Land Use, 2013).

${ }^{5}$ Chodzi o dyrektywę 2007/2/WE Parlamentu Europejskiego i Rady z dnia 14 marca 2007 r. ustanawiającą infrastrukturę informacji przestrzennej we Wspólnocie Europejskiej (INSPIRE). 


\section{TERYTORIALNY WYMIAR POLITYKI ROZWOJU - MINISTERSTWO ROZWOJU}

W kontekście kapitału terytorialnego Agenda terytorialna UE 2020, za nową geografią ekonomiczną, wskazuje na terytorialnie uwarunkowane niemobilne czynniki, których znaczenie wzrasta wraz z rosnącą globalizacją i zanikaniem bariery dostępności. Celem jest wyzwolenie potencjału terytorialnego za pomocą strategii rozwojowych, wykorzystywaniu atutów i czynników zwiększających konkurencyjność obszarów. Odpowiednio dobrane, zdefiniowane w systemie planowania i rozwoju regulacyjne dokumenty planistyczne, spójne ze strategiami, również mogłyby rozwijać ten potencjał i stymulować rozwój danego terytorium.

Wymiar terytorialny polityki rozwoju to uwzględnienie specyfik terytorialnych w działaniach rozwojowych. W praktyce wymiar terytorialny pomaga w tworzeniu dopasowanych indywidualnie interwencji oraz wspiera obszary, które z różnych względów borykają się z trudnościami rozwojowymi bądź posiadają charakterystyczne potencjały, wynikające ze specyficznych uwarunkowań przestrzennych, społecznych czy gospodarczych ${ }^{6}$. Zintegrowane podejście terytorialne polega na uwzględnianiu specyfiki terytorialnej na każdym etapie programowania (diagnozowanie potrzeb, wyznaczanie celów, projektowanie systemu realizacji i monitorowania) strategicznych działań i projektów, w celu efektywnego wykorzystania dostępnych środków finansowych i najlepszego dopasowania interwencji. Obecnie część diagnostyczna strategii krajowych (horyzontalnych) bazuje na danych regionalnych o zbyt dużej generalizacji. Ministerstwo Rozwoju ${ }^{7}$ zaleca wykonywanie analiz na poziomie NTS4, NTS5. Prezentacje danych powinny obrazować zróżnicowania terytorialne, na dowolnym poziomie agregacji danych. Kapitał terytorialny to zestaw możliwych specyficznych i różnorodnych zasobów materialnych i niematerialnych występujących na poszczególnych obszarach. Analiza kapitału terytorialnego jest niezbędna do zidentyfikowania potencjału terytorialnego, wynikającego z tych zasobów.

Rycina 2. Zasoby materialne i niematerialne
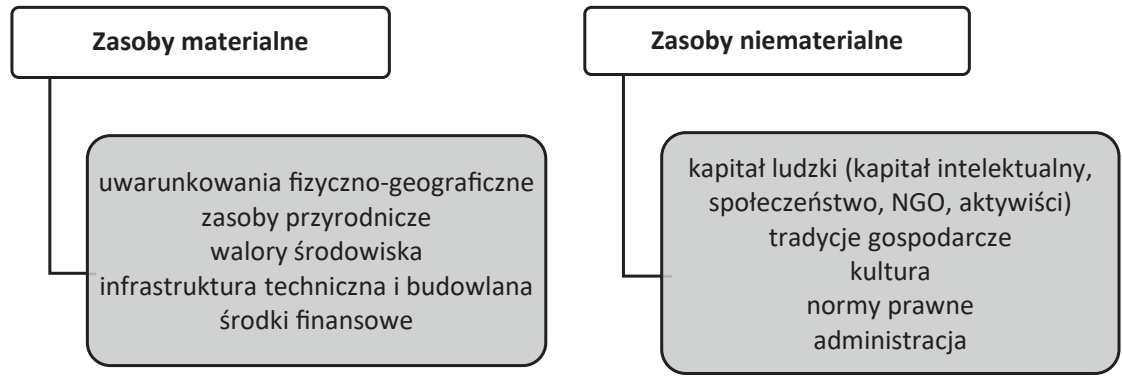

Źródło: Ministerstwo Rozwoju

${ }^{6}$ Na podstawie opinii Ministerstwa Rozwoju - udostępnienie 3.12.18 przez p. Sikorską, członka Zarządu TUP Warszawa.

${ }^{7}$ Definicja MR: Spójność terytorialna to stan rozwoju terytorium, w którym procesy wymiany i przepływów w sferze gospodarczej, społecznej, środowiskowej oraz instytucjonalnej przebiegają sprawnie, gwarantując wymierne efekty. Zintegrowane podejście terytorialne koncentruje się na przestrzennym wymiarze rozwoju społeczno-gospodarczego. Punktem odniesienia dla działań prowadzonych w ramach polityki regionalnej jest terytorium, charakteryzujące się określonym zbiorem cech (społecznych, przestrzennych, środowiskowych, gospodarczych), warunkujących jego potencjał endogeniczny (w tym zasoby terytorialne), bariery oraz potrzeby rozwojowe, które odróżniają je od innych terytoriów. 
Obszary strategicznej interwencji to wskazane w strategii rozwoju obszary ze specyficznym zestawem uwarunkowań i cech społecznych, gospodarczych lub przestrzennych, decydujących o występowaniu na ich terenie strukturalnych barier rozwoju lub trwałych, możliwych do aktywowania potencjałów rozwojowych (interwencja publiczna).

\section{WYNIKI BADAŃ REGIONALNYCH ZESPOŁU NAUKOWEGO}

Wyniki cząstkowe badań (2016-2017) były prezentowane w trzech publikacjach, w których szczegółowo opisano metodologię i wyniki badań. W tym artykule wybrano tylko wnioski natury ogólnej, które wpłynęły na decyzję kontynuowania badań w celu odpowiedzi na kolejne pytania badawcze wymienione na wstępie. Autorzy badań (zespół czteroosobowy reprezentujący trzy uczelnie) ${ }^{8}$ początkowo skupili się na poszukiwaniu inspiracji z analizy portali, geoportali urzędów marszałkowskich, jednorodnej bazy danych przestrzennych metropolii Poznań wykorzystanej do utworzenia „Kon-

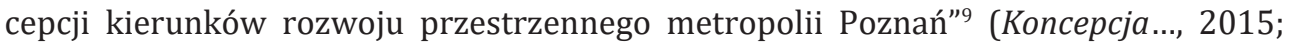
Mikuła, Kaczmarek, 2016), wywiadach, w tym z przedstawicielami: Instytutu Rozwoju Terytorialnego we Wrocławiu, Mazowieckiego Obserwatorium Terytorialnego, na bazie których powstała pierwsza propozycja treści ankiety badawczej (Stelmach-Fita, Pękalska, Bartoszczuk, 2017, 2018).

Wstępnie ustalono, że programowanie strategiczne, w tym regionalne, jest przede wszystkim podporządkowane zewnętrznym źródłom dofinansowania UE. W monitorowaniu polityki rozwoju w Polsce uwaga została skupiona na weryfikacji realizacji polityki spójności i związanych z nią wydatków, monitoringu i ewaluacji strategii rozwoju województwa. Określając kształt ROT, przywołano jako jego podstawę „Bank informacji o regionie"10 (Stelmach-Fita, Brodowicz, 2017; Grochowski, 2017). Natomiast autorów badań interesował stały monitoring rzeczywistych zmian w zagospodarowaniu przestrzennym (który mógłby stać się istotnym mechanizmem zintegrowanego planowania), zwłaszcza że narzędziem do niego mogłaby być Infrastruktura Informacji Przestrzennej integrująca wszystkie dane przestrzenne.

Zakres tematyczny ankiety przedyskutowano na spotkaniach z przedstawicielami ROT 15 i 16 grudnia 2016 roku w Ministerstwie Rozwoju. Autorka artykułu zaprezentowała referat pt. „ROT - nowy dialog terytorialny”. Zmodyfikowaną ankietę „Baza danych opisowych i przestrzennych o regionie” przesłano do urzędów 1 czerwca 2017 roku. Ankieta w preambule zawierała pytania dotyczące liczby wydawanych decyzji warunkujących zagospodarowanie przestrzenne, rejestrowanych w latach 20122016. Następne pytania skierowane zostały do jednostek:

A - infrastruktury informacji przestrzennej lub infrastruktury danych przestrzennych,

${ }^{8}$ B. Stelmach-Fita, Uniwersytet Pedagogiczny w Krakowie (koordynator), M. Pękalska, Uniwersytet Warszawski, P. Bartoszczuk i D. Brodowicz, Szkoła Główna Handlowa w Warszawie.

9 Zespół z Centrum Badań Metropolitalnych UAM w Poznaniu (CBM) za ww. Koncepcję otrzymał Nagrodę Prezesa Rady Ministrów (za rok 2017) - III miejsce w kategorii osiągnięć naukowo-technicznych.

${ }_{10}$ Zbiór opracowań, zestawienie linków do wybranych źródeł danych i informacji oraz zestawienie wybranych jednostek istotnych ze względu na monitoring rozwoju i kształtowanie przestrzeni społeczno-gospodarczej regionu; uwzględnia raporty i analizy - zestawienie opracowań przydatnych do monitorowania rozwoju regionu, których autorami są jednostki rządowe i samorządowe różnego szczebla, instytucje naukowe i firmy komercyjne (Informacje i dane dostępne online) (RCAS, 2013). 
B - biura planowania przestrzennego (polityka przestrzenna na poziomie regionalnym),

$\mathrm{C}$ - regionalnego obserwatorium terytorialnego (baza danych społeczno-gospodarczych i przestrzennych o regionie).

Na 16 urzędów odpowiedzi pisemnych udzieliło 14. Pierwsze pytanie dotyczyło udostępniania w węźle IIP/IDP planu zagospodarowania województwa (PZPW). Odpowiedzi były różne. Pięć odpowiedzi wskazywało na udostępnianie tego planu w ramach IIP. Były dwie odpowiedzi „nie” bez komentarza oraz siedem odpowiedzi „nie” z uzasadnieniem, że nie ma wytycznych ani przepisów w tym zakresie, a dane są udostępniane w Biuletynie Informacji Publicznej (BIP). Przywołuje się poniżej istotną wypowiedź z województwa dolnośląskiego: „Brak przepisów odnośnie do kompetencji i praw marszałka do udostępniania danych zawartych w planach wojewódzkich pochodzących z wielu źródeł posiadających wielu dysponentów, udostępniających własne dane na różnych zasadach licencyjnych". Z odpowiedzi z województw: łódzkiego, lubuskiego, podkarpackiego, pomorskiego, wielkopolskiego wynikało, że PZPW jest udostępniany za pośrednictwem usług danych przestrzennych wyszukiwania, przeglądania. W zachodniopomorskim zamierzano opublikować PZPW po zakończeniu budowy węzła IIP. W lubuskim nie udostępniono planu, ponieważ nie było jeszcze węzła IIP. W małopolskim jest link do udostępnionego planu. W mazowieckim PZPW jest udostępniany za pośrednictwem usług sieciowych WMS i WFS oraz na stronie BIP. Opolskie i podlaskie udostępniły plan w usłudze WMS. Odpowiedzi z województwa śląskiego wskazały na problem braku wytycznych technicznych dotyczących sporządzania planu województwa. Niezależnie od tego udostępniono plan na stronie BIP.

Odnośnie do pytań z części B generalnie zdecydowana większość respondentów odpowiedziała, że dane przestrzenne dotyczące wymienionych w ankiecie kilku „decyzji specjalnych" są potrzebne do aktualizacji planów zagospodarowania przestrzennego i każdorazowo są one manualnie przetwarzane do potrzeb wprowadzenia do bazy danych tworzonego planu (nie są te dane przestrzenne w żaden sposób udostępniane w IIP np. jako mapy lokalizacji decyzji).

Odnośnie do pytania z części C, skierowanego do ROT, o jednolitą strukturę portalu $\mathrm{z}$ „Bazą wiedzy o regionie” odpowiedzi można podzielić na dwa rodzaje. W pierwszym z nich, stanowiącym większość, wskazywano na zainteresowanie jednolitą strukturą i przedstawiono nawet dodatkowe propozycje lub zgłoszono potrzebę jego doprecyzowania. Wspomniano o potrzebie przyporządkowania przykładowych mierników do źródeł ich pozyskania odnoszących się do wymienionych pięciu grup wskaźników. Z pozostałych odpowiedzi wynikało małe zainteresowanie ujednolicaniem struktury portali ze względu na zakończone prace z tym związane. Brak odpowiedzi tylko z województwa świętokrzyskiego.

Natomiast przedstawiciel UM Województwa Kujawsko-Pomorskiego (Z. Wejer, w 2017 roku) ${ }^{11} \mathrm{w}$ udzielonym wywiadzie przedstawił stanowisko, że nie popiera on udostępniania w regionalnym węźle IIP brakujących w nim danych przestrzennych dotyczących „decyzji specjalnych”, ponieważ oznaczałoby to utrwalenie ich funkcjonowania w systemie prawnym. W rozmowie wskazał na potrzebę wzmocnienia kadr w biurach planowania przestrzennego i rozwoju na poziomie wojewódzkim, w tym

11 Materiały związane z przeprowadzonymi wywiadami dostępne u autorki artykułu. 
większego udziału specjalistów planowania przestrzennego, jak również potrzebę ich współpracy z ROT oraz jednostkami ds. IIP.

Z wyników badań wynika, że zidentyfikowane problemy są spowodowane wadliwym stanem prawnym, brakiem wytycznych co do udostępniania planu województwa w IIP. Potrzebne są również regulacje prawne lub standardy co do zakresu i sposobu sporządzania planów zagospodarowania przestrzennego województwa. Respondenci potwierdzili, że funkcjonujące kilka typów decyzji (w tym decyzje specjalne) i dane przestrzenne w nich zawarte są potrzebne do tworzenia i aktualizacji planów. Potwierdzono również, że istnieją możliwości technologiczne i organizacyjne udostępniania nowych zbiorów danych „lokalizacji ww. decyzji” w IIP pod warunkiem nadania im georeferencji i wprowadzenia regulacji.

\section{Działania w Pomorskim Biurze Planowania Rozwoju w Gdańsku}

\section{Informacje ustalone na podstawie wywiadów z pracownikami}

Autorka artykułu przeprowadziła w 2012 roku badanie w zakresie działań podejmowanych w województwie dolnośląskim, na podstawie materiałów udostępnionych w Instytucie Rozwoju Terytorialnego we Wrocławiu. Bardzo dobrze ocenione działania zainspirowały autorkę do kontynuacji badań w innym województwie. W IRT ujednolicono strefy polityki przestrzennej w studiach uwarunkowań i kierunków zagospodarowania w celu doporowadzenia ich do spójności ze strefami klasyfikacji Urban Atlas/ Atlas Miejski, która z kolei jest spójna z klasyfikacją HILUCS INSPIRE. Od roku 2009 w IRT prowadzony jest monitoring ww. stref oraz wspierana jest polityka przestrzenna gmin, które wnioskowały o takie wsparcie.

Celem tej części badań było rozpoznanie mechanizmów zintegrowanego planowania mających wpływ na kształtowanie i rozwój terenów przemysłowo-usługowych.

Informacje zawarte w tej części artykułu pochodzą z wywiadów przeprowadzonych przez autorkę z pracownikami PBPR w Gdańsku ${ }^{12}$, m.in. w ramach trzech spotkań w PBPR w Gdańsku: 20 kwietnia, 7 czerwca 2018 roku i 9 lipca 2019 roku (z J. Pietruszewskim, A. Łoziak i M. Radzikowskim) oraz 3 i 4 grudnia 2018 roku (z W. Kuczabskim - wspólny referat ${ }^{13}$ ).

W rozmowie ponadto zwrócono uwagę na brak czytelnego modelu systemu planowania przestrzennego $\mathrm{w}$ systemie rozwoju. Jednym z najpoważniejszych problemów z tym związanych okazał się problem braku możliwości realizacji inwestycji drogowych z powodu wydania wielu decyzji o warunkach zabudowy na projektowanym obszarze. „Nawet najlepsze technologie i profesjonalne wielowariantowe analizy przestrzenne nic nie pomogą, jeżeli będą funkcjonowały decyzje o warunkach zabudowy, które obecnie uniemożliwiają projektowanie perspektywiczne inwestycji drogowych" (Pietruszewski) $^{14}$.

\footnotetext{
12 Autorka zainteresowała się referatem J. Pietruszewskiego wygłoszonym 20 kwietnia 2018 roku podczas I spotkania Metropolitalnej Sieci Naukowej w Gdańsku - Instytut Metropolitalny z Gdańska.

${ }_{13}$ Referat na 34 Międzynarodowej Konferencji Naukowej nt. „Problematyka badań geografii przemysłu i usług” organizowanej przez Instytut Geografii Uniwersytetu Pedagogicznego w Krakowie, 3-4 grudnia 2018 r.

14 Materiały z wywiadów u autorki artykułu.
} 
Z wywiadu 9 lipca 2019 roku (Pietruszewski) wynikało, że „zintegrowane planowanie polegać powinno przede wszystkim na integracji procesów i prowadzeniu dialogu terytorialnego, a nie na uproszczonym rozumieniu integracji w sensie łączenia dokumentu strategii rozwoju województwa z planem zagospodarowania przestrzennego województwa". Każde województwo posiada inną specyfikę (np. obszary nabrzeżne, przygraniczne czy kształtującej się metropolii). Strategia jest dokumentem innego typu.

Autorka potwierdza, że zagadnienie „pozyskiwania w ostatnich latach decyzji o warunkach zabudowy, często do celów spekulacyjnych z zamiarem otrzymania odszkodowania” było przedmiotem najbardziej burzliwej części dyskusji na „Seminarium eksperckim - Regulacyjna rola miejscowych planów" w dniu 8 czerwca 2018 roku w Urzędzie Miasta Sopot ${ }^{15}$.

Jest to jeden z najpoważniejszych problemów, będący argumentem do potrzebnej zmiany stanu prawnego, aby o uwarunkowaniach zagospodarowania przestrzennego nie decydowały na dużą skalę jednoosobowe organy wydające decyzje lokalizacyjne lub orzeczenia sądowe. Bez tej zmiany opisywane dalej działania nie będą mogły w pełni odnieść zamierzonego efektu.

Odnośnie do innych mechanizmów integrujących planowanie, które próbowano wdrożyć we wszystkich gminach z obszaru metropolitalnego, to wypracowano jednolity standard zapisu SUiKZPG dla Gdańska. Wspomniano również o potrzebie umocowania prawnego wieloletniej prognozy finansowej w przypadku długoletnich inwestycji. Przekazano autorce prezentację z modelem zintegrowanego planowania na poziomie wojewódzkim J. Pietruszewskiego, prezentowanym na spotkaniu jednostek samorządu terytorialnego w kwietniu 2018 roku.

\section{Informacje ustalone na podstawie przekazanych materiałów}

W samorządzie województwa pomorskiego istotnym uwarunkowaniem podejmowanych działań są próby integracji planowania przestrzennego z polityką rozwojową. Podejście terytorialne znajduje czytelne odzwierciedlenie w doborze odpowiednich instrumentów rozwojowych. W perspektywie finansowej 2014-2020, poza pakietem działań w ramach zintegrowanych inwestycji terytorialnych dla obszaru metropolitalnego, uwzględniony został również analogiczny mechanizm dla innych funkcjonalnych obszarów miejskich - zintegrowane porozumienia terytorialne. Bardzo istotnym elementem prowadzącym do stworzenia silnej metropolii jest przygotowanie narzędzi niezbędnych do integracji gmin sąsiadujących w pierścieniu rdzenia metropolii. Zakres przedsięwzięć negocjowany był w długim partnerskim procesie, przy udziale różnych interesariuszy oraz przy uwzględnieniu zasad polityki przestrzennej województwa, na długo przed uruchomieniem środków finansowych koordynowanych przez samorząd województwa.

Do delimitacji strategicznych obszarów rozwoju funkcji metropolitalnych potrzebne były dokładne informacje o lokalizacjach wszystkich inwestycji realizowanych i planowanych na terenie całego województwa. M. Radzikowski i A. Łoziak utworzyli aplikację umożliwiającą pracownikom urzędów gmin wpisywanie, na udostępnionej

${ }^{15}$ Autorka artykułu była prelegentką na seminarium organizowanym przez Instytut Metropolitalny z Gdańska z referatem nt. „Problemy ze sporządzaniem miejscowych planów”, a później uczestnikiem dyskusji, w której mieszkańców najbardziej interesowały interpretacje przepisów i rozstrzygnięć sądowych dotyczących decyzji. 
linkiem mapie, lokalizacji inwestycji budowlanych wraz z georeferencją (obiekt punktowy, liniowy lub poligon).

Udostępniono wszystkim instrukcję do ankiety w podziale na 11 kategorii inwestycji: infrastruktura społeczna, infrastruktura transportowa, infrastruktura turystyki, infrastruktura wodno-kanalizacyjna, infrastruktura ochrony przeciwpowodziowej, infrastruktura gospodarki odpadami, infrastruktura energetyczna, infrastruktura telekomunikacyjna, zasoby dziedzictwa kulturowego, tereny inwestycyjne, infrastruktura bezpieczeństwa.

Odnosząc się do problematyki kształtowania i rozwoju terenów przemysłowo-usługowych PBPR, w ramach prac nad planem województwa (PZPWP 2030) oraz stanowiącym jego część Planem zagospodarowania przestrzennego Obszaru Metropolitalnego Gdańsk-Gdynia-Sopot 2030 (PZP OM G-G-S 2030), określiło:

I. Zasady zagospodarowania przestrzennego dotyczące kształtowania i rozwoju terenów inwestycyjnych (pod działalność gospodarczą, w tym usługową);

II. Delimitację strategicznych obszarów rozwoju funkcji metropolitalnych (w tym terenochłonnych funkcji gospodarczych oraz terenochłonnych usług o charakterze metropolitalnym związanych z funkcjami: sportu i rekreacji);

- zapisy Planu posiadające rangę ustaleń i stanowiące podstawę wydania postanowień o uzgodnieniu lub odmowie uzgodnienia projektów lokalnych dokumentów planistycznych;

- zapisy Planu niebędące ustaleniami są przedmiotem dyskusji w ramach funkcjonującego w województwie pomorskim instrumentu wdrażania dialogu terytorialnego (podejmowanego z każdą zainteresowaną JST, w szczególności w momencie przystąpienia do sporządzania lub zmiany SUiKZP).

Zasady zagospodarowania (określone w Planie) wykorzystywane są również w innych działaniach samorządu województwa pomorskiego, m.in. do formułowania kryteriów konkursowych dotyczących ubiegania się o dofinansowanie ze środków UE np. w ramach Regionalnego Programu Operacyjnego.

Zasady zagospodarowania przestrzennego dotyczące kształtowania i rozwoju terenów inwestycyjnych uwzględniają konkretne parametry związane z uwarunkowaniami (potencjałami) lokalizacyjnymi - jako jedno z kryteriów rankingowania terenów inwestycyjnych w ofercie regionalnej agencji rozwoju. Zasady ukierunkowanie są na ograniczenie zagospodarowywania nowych terenów, wykorzystanie lokalizacji o najlepszych uwarunkowaniach oraz rozróżnienie dwóch zasadniczych kategorii: brown field i green field.

Zasady uwzględnione zostały w treści dokumentów planistycznych - PZPWP i PZP OM G-G-S 2030, w ramach kierunku polityki przestrzennej 2.2. Kształtowanie struktur przestrzennych umożliwiających tworzenie nowych i trwałych miejsc pracy:

- Zasada wielofunkcyjnego kształtowania struktur przestrzeni gospodarczej w sposób minimalizujący występowanie konfliktów przestrzennych.

- Zasada rozwoju terenów inwestycyjnych (pod działalność gospodarczą, w tym usługową):

1. wykorzystujących w pierwszej kolejności tereny zainwestowane gospodarczo (brown field), w tym poprzemysłowe, pokolejowe, powojskowe, popegeerowskiej zabudowy;

2. w nowych lokalizacjach (green field) dopiero w przypadku wyczerpania zasobów przestrzeni możliwych do ponownego zagospodarowania (brown field), 
szczególnie terenów zdegradowanych, lub w sytuacji braku terenów o odpowiednich parametrach i uwarunkowaniach formalnoprawnych, przy czym zainwestowanie to musi uwzględniać wymogi ładu przestrzennego i wynikać z uzasadnionej potrzeby;

3. w bezpośrednim zasięgu oddziaływania istniejących kompleksów przemysłowych;

4. odpowiednio powiązanych z układem drogowym i kolejowym;

5. posiadających możliwości obsługi przez transport zbiorowy;

6. posiadających odpowiednią powierzchnię umożliwiającą wyznaczenie terenów zieleni buforowej, minimalizującej negatywne oddziaływanie tych terenów na obszary sąsiednie (np. w celu zmniejszenia zagrożenia hałasem).

- Zasada planowania strategicznych terenów inwestycyjnych (pod działalność usługową), co oznacza, że powinny one:

1. mieć co najmniej 20 ha powierzchni jako zwarty teren, co umożliwia lokalizację różnorodnych funkcji gospodarczych,

2. dla zwiększania potencjału inwestycyjnego i wykorzystania istniejącej infrastruktury technicznej tworzyć komplementarną całość w powiązaniu z istniejącymi terenami zabudowy produkcyjnej lub usługowej,

a) być korzystnie położone względem infrastruktury transportowej, przez ich zlokalizowanie: w maksymalnej odległości do $3 \mathrm{~km}$ od węzłów drogowych (...),

3. być kompleksowo wyposażone w infrastrukturę techniczną,

4. posiadać sprecyzowany profil zainwestowania gospodarczego, uwzględniający uwarunkowania i ograniczenia społeczne, środowiskowe, gospodarcze miejsca i jego otoczenia, w szczególności o funkcji mieszkaniowej.

- Zasada tworzenia warunków przestrzennych dla lokalizacji co najmniej jednego inkubatora przedsiębiorczości w powiecie, nawiązującego do lokalnego potencjału gospodarczego.

- Zasada zapewnienia równomiernego dostępu do szerokopasmowego internetu o parametrach co najmniej $30 \mathrm{Mb} / \mathrm{s}$.

Celem delimitacji była identyfikacja terenów o dobrych uwarunkowaniach dla lokalizacji terenochłonnych funkcji gospodarczych - zabezpieczenie ich przed przypadkowym zagospodarowaniem. Poniżej przybliżono metodę delimitacji ${ }^{16}$.

Dokonano analizy potencjałów i ograniczeń, a następnie ich syntezy. Identyfikując tereny pod rozwój funkcji gospodarczych, przyjęto trzy zasadnicze typy terenów pod inwestycje gospodarcze, odpowiadające specyfice funkcji metropolitalnych, rozróżnione z uwagi na funkcję, jak i stopień oddziaływania (możliwe potencjalne konflikty przestrzenne):

1. pod inwestycje przemysłu uciążliwego, przedsięwzięć zawsze znacząco oddziałujących na środowisko i zakładów stwarzających ryzyko poważnej awarii przemysłowej;

2. pod inwestycje lekkiej produkcji, baz, składów oraz usług z zakresu przedsięwzięć mogących potencjalnie znacząco oddziaływać na środowisko;

${ }^{16}$ Metodyka, ww. tabele i mapy przygotowane w ramach opracowania eksperckiego „Dostępność terenów inwestycyjnych oraz możliwości rozwoju mieszkalnictwa w Obszarze Metropolitalnym Gdańsk-GdyniaSopot” autorstwa Przedsiębiorstwa Projektowo-Realizacyjnego „DOM” Sp. z o.o. i Proeko (Gdańsk, wrzesień 2015 r.). 
3. pod inwestycje terenochłonnych usług o charakterze metropolitalnym, związanych z funkcjami: sport, rekreacja i zielona infrastruktura (parki rozrywki, centra rekreacyjne).

W celu identyfikacji ww. terenów przeprowadzono analizę potencjałów i ograniczeń. Zarówno potencjały, jak i ograniczenia lokalizacyjne analizowane były z uwzględnieniem określonych kategorii i kryteriów. Potencjały rozpatrywano w czterech grupach zagadnień:

1. transport (dziewięć kryteriów związanych z dostępnością transportu drogowego, kolejowego, lotniczego i morskiego);

2. infrastruktura techniczna (trzy kryteria, dostępność energii elektrycznej i gazu ziemnego);

3. istniejące zagospodarowanie i użytkowanie terenu (trzy kryteria związane z istniejącym lub potencjalnym zainwestowaniem gospodarczym na obszarach wybranych przez gminy);

4. planowane zagospodarowanie terenu związane $\mathrm{z}$ istniejącą zabudową, zainwestowaniem.

Zidentyfikowano kilka typów ograniczeń: środowiskowe i wynikające z dziedzictwa kulturowego oraz z istniejącego i planowanego zagospodarowania.

\section{Synteza}

Delimitacji terenów inwestycyjnych dokonano, biorąc pod uwagę obszary pozbawione ograniczeń lokalizacyjnych lub posiadające ograniczenia uznaniowe, ze szczególnym uwzględnieniem następujących kryteriów:

- dostępność komunikacyjna: drogowa, kolejowa, morska, rzeczna, lotnicza,

- dostępność infrastruktury technicznej: elektroenergetyczna, gazownicza, wodno-kanalizacyjna,

- stan antropizacji środowiska: tereny poinwestycyjne (brown field), tereny niezainwestowane, głównie rolnicze i porolnicze (green field),

- sąsiedztwo przyrodnicze (ograniczenia lokalizacyjne): formy ochrony przyrody i krajobrazu, elementy osnowy ekologicznej, zwłaszcza korytarze ekologiczne, rejony o szczególnych walorach przyrodniczych rozwoju funkcji rekreacyjno-turystycznych,

- sąsiedztwo zurbanizowane (jako ograniczenia lokalizacyjne).

\section{Delimitacja umocowana w dokumentach planistycznych województwa pomorskiego}

W kierunku 2.1. Rozwój funkcji metropolitalnych zidentyfikowane zostały strategiczne obszary rozwoju funkcji metropolitalnych wraz z poświęconymi im działaniami i przedsięwzięciami. „Smart metropolia” zawiera zrównoważone wykorzystanie potencjału rozwoju funkcji metropolitalnych", wskazane zostały zasięgi potencjałów lokalizacyjnych i granice poszczególnych strategicznych obszarów opisanych w treści planu. 
Tabela 1. Wybrane, przykładowe potencjały sprzyjające lokalizacji

\begin{tabular}{|c|c|c|c|}
\hline Lp. & $\begin{array}{l}\text { Opis potencjału sprzyjającego } \\
\text { lokalizacji }\end{array}$ & $\begin{array}{c}\text { Zasięg } \\
\text { oddziaływania } \\
\text { potencjału }\end{array}$ & Uwagi \\
\hline \multicolumn{4}{|c|}{ TRANSPORT } \\
\hline 1 & $\begin{array}{l}\text { Położenie w odległości do } 3 \mathrm{~km} \text { od } \\
\text { istniejących i projektowanych węzłów } \\
\text { autostrady A1, dróg ekspresowych S6 } \\
\text { i S7 oraz obwodnic (...). }\end{array}$ & $\begin{array}{l}\text { Ponadlokalny - } \\
\text { krajowy }\end{array}$ & $\begin{array}{l}\text { Przebiegi dróg istniejących, } \\
\text { projektowanych oraz węzłów } \\
\text { drogowych (istniejących i projekt.). } \\
\text { Ze względu na ograniczoną dostępność } \\
\text { drogi przyjęto odległość od węzłów. }\end{array}$ \\
\hline 2 & $\begin{array}{l}\text { Położenie w odległości do } 1 \text { km } \\
\text { w pasie wzdłuż dróg krajowych } \\
\text { i wojewódzkich. }\end{array}$ & Lokalny & $\begin{array}{l}\text { Przebiegi dróg istniejących } \\
\text { i projektowanych. Kryterium } \\
\text { określa możliwość lokalizacji } \\
\text { terenów inwestycyjnych w zasięgu } \\
\text { projektowanego bezpośredniego } \\
\text { zjazdu z drogi. }\end{array}$ \\
\hline 3 & $\begin{array}{l}\text { Położenie w odległości do } 1 \text { km od } \\
\text { stacji i przystanków kolejowych na } \\
\text { czynnych liniach kolejowych. }\end{array}$ & $\begin{array}{l}\text { Ponadlokalny - } \\
\text { krajowy }\end{array}$ & $\begin{array}{l}\text { Lokalizacja stacji i przystanków } \\
\text { kolejowych. Kryterium ważne } \\
\text { w szczególności dla działalności } \\
\text { wykorzystujących transport kolejowy. }\end{array}$ \\
\hline 4 & $\begin{array}{l}\text { Położenie w odległości do } 5 \text { km od } \\
\text { portów w Gdańsku i Gdyni. }\end{array}$ & $\begin{array}{l}\text { Ponadlokalny - } \\
\text { międzynarodowy }\end{array}$ & $\begin{array}{l}\text { Lokalizacja portów. Kryterium ważne } \\
\text { w szczególności dla działalności } \\
\text { związanych z gospodarką morską. }\end{array}$ \\
\hline 5 & $\begin{array}{l}\text { Położenie w odległości do } 3 \mathrm{~km} \\
\text { od portów i przystani o potencjale } \\
\text { gospodarczym. }\end{array}$ & $\begin{array}{l}\text { Ponadlokalny - } \\
\text { międzynarodowy }\end{array}$ & $\begin{array}{l}\text { Lokalizacja portów i przystani. Dotyczy } \\
\text { portów i przystani posiadających } \\
\text { możliwości przeładunku towarów, } \\
\text { w tym projektowanych do rozwoju } \\
\text { takich funkcji (...). }\end{array}$ \\
\hline 7 & $\begin{array}{l}\text { Położenie w granicach dobrej } \\
\text { dostępności kolejowej istniejącego } \\
\text { portu lotniczego (Port Lotniczy } \\
\text { im. L. Wałęsy) - do } 500 \text { m od } \\
\text { przystanków PKM. }\end{array}$ & $\begin{array}{l}\text { Ponadlokalny - } \\
\text { międzynarodowy }\end{array}$ & $\begin{array}{l}\text { Przebiegi linii kolejowej oraz } \\
\text { planowanych przystanków PKM. } \\
\text { Kryterium sprzyja dostępności } \\
\text { terenów inwestycyjnych } \\
\text { prowadzących działalności na arenie } \\
\text { międzynarodowej. }\end{array}$ \\
\hline 9 & $\begin{array}{l}\text { Położenie nieruchomości w granicach } \\
\text { dobrej dostępności potencjalnego } \\
\text { portu lotniczego (Kosakowo) } 5 \mathrm{~km} \text { od } \\
\text { lotniska. }\end{array}$ & $\begin{array}{l}\text { Ponadlokalny - } \\
\text { międzynarodowy }\end{array}$ & $\begin{array}{l}\text { Zasięg portu lotniczego. Kryterium } \\
\text { sprzyja dostępności terenów } \\
\text { inwestycyjnych prowadzących } \\
\text { działalności na arenie } \\
\text { międzynarodowej. }\end{array}$ \\
\hline \multicolumn{4}{|c|}{ INFRASTRUKTURA TECHNICZNA } \\
\hline 10 & $\begin{array}{l}\text { Położenie w zasięgu dostępności gazu } \\
\text { przewodowego. }\end{array}$ & Lokalny & $\begin{array}{l}\text { Kryterium dotyczy terenów } \\
\text { inwestycyjnych o specyfice } \\
\text { produkcji wymagającej dostępności } \\
\text { sieci gazowej. Plany rozwoju } \\
\text { sieci gazowej są dostosowywane } \\
\text { do zapotrzebowania odbiorców } \\
\text { i możliwości rozbudowy sieci. }\end{array}$ \\
\hline 11 & $\begin{array}{l}\text { Położenie w obszarze przewidywanym } \\
\text { do gazyfikacji. }\end{array}$ & Lokalny & $\begin{array}{l}\text { Dotyczy terenów inwestycyjnych } \\
\text { o specyfice produkcji wymagającej } \\
\text { dostępności sieci gazowej. }\end{array}$ \\
\hline 12 & $\begin{array}{l}\text { Położenie w dobrej dostępności sieci } \\
\text { elektroenergetycznej wysokich napięć - } \\
\text { możliwość bezpośredniego włączenia } \\
\text { w stację elektroenergetyczną. }\end{array}$ & $\begin{array}{l}\text { Ponadlokalny - } \\
\text { krajowy }\end{array}$ & $\begin{array}{l}\text { Kryterium dotyczy terenów } \\
\text { inwestycyjnych o specyfice produkcji } \\
\text { energochłonnej. Na załączniku } \\
\text { kartograficznym oznaczono stacje } \\
\text { elektroenergetyczne o zasięgu } \\
\text { krajowym 400/110kV. }\end{array}$ \\
\hline
\end{tabular}




\begin{tabular}{|c|c|c|c|}
\hline \multicolumn{4}{|c|}{ ZAGOSPODAROWANIE I UŻYTKOWANIE TERENU } \\
\hline 13 & $\begin{array}{l}\text { Istniejąca zabudowa i zainwestowanie - } \\
\text { zabudowa o funkcji usługowej, } \\
\text { produkcyjnej, magazyny i składy, w tym } \\
\text { tereny nieużytkowane. }\end{array}$ & Lokalny & $\begin{array}{l}\text { Tereny zabudowane (także obecnie } \\
\text { nieużytkowane) stanowią potencjał } \\
\text { rozwojowy terenów inwestycyjnych } \\
\text { na obszarach tzw. brown field. }\end{array}$ \\
\hline \multicolumn{4}{|c|}{ PLANOWANE ZAGOSPODAROWANIE TERENU wg polityk przestrzennych gmin } \\
\hline 14 & $\begin{array}{l}\text { Planowana zabudowa o funkcji } \\
\text { produkcyjnej, produkcyjno-usługowej, } \\
\text { magazynów i składów (bez zabudowy } \\
\text { mieszkaniowej towarzyszącej). }\end{array}$ & Lokalny & \multirow{3}{*}{$\begin{array}{l}\text { Wyznaczono na podstawie } \\
\text { obowiązujących SUiKZP. } \\
\text { Zgodność terenów rozwojowych } \\
\text { z polityką przestrzenną gmin. }\end{array}$} \\
\hline 15 & $\begin{array}{l}\text { Planowana zabudowa - obszary } \\
\text { planowanej zabudowy wielofunkcyjnej. }\end{array}$ & Lokalny & \\
\hline 16 & $\begin{array}{l}\text { Planowana zabudowa o funkcji } \\
\text { usługowej. }\end{array}$ & Lokalny & \\
\hline
\end{tabular}

Źródło: Pomorskie Biuro Planowania Regionalnego w Gdańsku

\section{WYWIADY POGŁĘBIONE - WERYFIKACJA WYNIKÓW BADAŃ}

\section{Komisja ds. Planowania Przestrzennego - Towarzystwo Urbanistów Polskich Warszawa}

Wyniki swoich badań autorka poddawała dyskusjom w ramach comiesięcznych spotkań (od maja 2018 r. do 20 maja 2019 r.) Zespołu ds. Planowania Przestrzennego im. Prousta, działającego przy Oddziale Warszawskim Towarzystwa Urbanistów Polskich. Zespół przygotował tezy, wytyczne dla zintegrowanego planowania. Dynamiczne planowanie zintegrowane (przestrzenne i społeczno-gospodarcze) jest warunkiem koniecznym do poprawy racjonalności wydatkowania środków budżetowych na cele rozwoju przestrzennego. M. Świetlik, jako kierownik zespołu, włączył „wieloletnią prognozę finansową" do wspólnie wypracowanego modelu zintegrowanego planowania na poziomie lokalnym. Poniżej wymieniono wypracowane tylko te tezy, które związane są z pytaniami badawczymi:

- Poziomem planowania o aktualnie największym potencjale dla wdrożenia mechanizmów planowania zintegrowanego jest poziom regionalny (wojewódzki).

- Tworzenie nowej metodyki planowania wymaga integracji nauki z praktyką. Na szczeblu centralnym mógłby to być krajowy ośrodek badawczo-wdrożeniowy, a na szczeblu wojewódzkim - regionalne ośrodki wdrożeniowe, które dodatkowo szkoliłyby kadry dla przyszłych planistycznych ośrodków powiatowych (obsługujących planistycznie gminy wchodzące w skład powiatów).

- Powinien być skonstruowany program etapowego przechodzenia od współzależności planowania społeczno-gospodarczego i przestrzennego do ich pełnej integracji. Dzięki temu nieliczne i rozproszone kadry fachowe planowania społeczno-gospodarczego będą mogły uczestniczyć w większej ilości prac planistycznych. Dotyczy to także kadr planowania przestrzennego - ciągle zbyt nielicznych i nie do końca przygotowanych do nowych wyzwań. Przyczyniła się do tego także likwidacja Izby Urbanistów.

- Rekomenduje się miejscowy plan ogólny - obowiązkowy dla dużych miast/obszaru całej gminy lub kilku gmin, który powinien być wieloskalarny i posiadać część rozwojową ogólną (kierunkową i perspektywiczną) obejmującą cały obszar 
miasta i części szczegółowe dla wybranych obszarów miasta (regulacyjne). Wspomniana część rozwojowa mogłaby nazywać się „Koncepcja rozwoju miast/gminy/ kilku gmin".

- Zintegrowane planowanie - z udziałem grup interesariuszy (I - władze samorządowe, II - inwestorzy-deweloperzy, III - mieszkańcy, stowarzyszenia, ruchy miejskie).

\section{UPC - Universitat Politechnica De Catalunya Barcelonatech}

Wybrane kwestie autorka poddała dyskusji 28 czerwca 2019 roku w Barcelonie z profesorami tej uczelni, w tym profesorem R.M. Biere'em Areasem (2019). Od 1956 roku w systemie prawnym Hiszpanii ${ }^{17}$ obowiązuje podział gruntów na trzy klasy (I - przeznaczone do urbanizacji, II - możliwej urbanizacji, III - nie do urbanizacji). Podkreślić należy, że w Hiszpanii funkcjonuje 9 typów planów, w tym 4 dotyczące planowania terytorialnego (1 - plan ogólny terytorialny, 2 - częściowy plan terytorialny, 3 - sektorowy plan, 4 - koordynujący plan terytorialny) oraz 5 - projektowania urbanistycznego (poziom ponadlokalny: 1 - plan urbanistyczny koordynujący, poziom lokalny: 2 - plan ogólny obowiązkowy dla dużych miast, poziom sublokalny: 3 - urban improvement plan / urbanistyczny plan poprawy, 4 - partial plan / częściowy plan, 5 - special plan / specjalny plan).

Na pewno mechanizmem zintegrowanego planowania jest stabilny podział na trzy klasy gruntów oraz dwa typy planów koordynujących zarówno terytorialny, jak i urbanistyczny.

System planowania Hiszpanii dostępny jest na stronie https://www.boe.es/legislacion/codigos, w zakładce „Derecho Urbanístico” (BOE, 2019), a Land Use w Hiszpanii - https://www.oecd.org/regional/regional-policy/land-use-Spain.pdf (The Governance of Land Use, 2019).

\section{REZULTATY I DYSKUSJA}

Zintegrowane planowanie wymaga kompleksowego podejścia i przygotowania całościowego modelu „Planowania przestrzennego w zintegrowanym systemie rozwoju”. Potrzebne są dyskusja i rozwinięcie badań w zasygnalizowanych kwestiach. Nowa metodyka planowania wymaga integracji nauki z praktyką. Na szczeblu centralnym mógłby to być krajowy ośrodek badawczo-wdrożeniowy, a na szczeblu wojewódzkim - regionalne ośrodki wdrożeniowe, które dodatkowo szkoliłyby kadry dla przyszłych planistycznych ośrodków powiatowych (obsługujących planistycznie gminy wchodzące w skład powiatów).

Poziom regionalny, wojewódzki wydaje się być poziomem o największym potencjale do wdrażania mechanizmów zintegrowanego planowania i dlatego potrzebne jest wzmocnienie kadr planistycznych na tym poziomie zarządzania.

Najistotniejsze mechanizmy zintegrowanego planowania, które były omawiane w artykule, a które mogą mieć wpływ na kształtowanie i rozwój terenów przemysłowo-usługowych, to:

- czytelny system prawny spójny z prawodawstwem UE;

\footnotetext{
17 Stan prawny systemu planowania: tasacion.es/ext/pdf/informacion_mercado/informe_legislacion_ urbanistica_2013.pdf.
} 
- monitoring zmian społeczno-gospodarczych i przestrzennych na każdym poziomie zarządzania mający ciągły charakter;

- udział w planowaniu grup interesariuszy (I - władze samorządowe, II - inwestorzy-deweloperzy, III - mieszkańcy, stowarzyszenia, ruchy miejskie);

- infrastruktura informacji przestrzennej - wykorzystanie tkwiących w niej możliwości (na poziomie krajowym);

- czytelny model planowania przestrzennego w zintegrowanym systemie rozwoju (na poziomie regionalnym);

- wspieranie przez wojewódzkie służby planistyczne polityki przestrzennej gmin, w problemach zgłaszanych przez te jednostki, jak i poprzez monitoring stref polityki przestrzennych ujednoliconych z klasyfikacją Urban Atlas / Atlas Miejski / HILUCS połączony z monitoringiem obserwacji Ziemi;

- regionalny plan kształtowania struktury przestrzennej (który powinien zastąpić obecny plan zagospodarowania województwa);

- koncepcja kierunków rozwoju przestrzennego metropolii z jednorodną bazą danych;

- dialog terytorialny wypracowywany w procesie negocjacji;

- metoda delimitacji strategicznych obszarów rozwoju funkcji metropolitalnych uwzględniająca poświęcone im działania i przedsięwzięcia;

- szczegółowe zasady zagospodarowania przestrzennego wprowadzone w planie na poziomie województwa dotyczące kształtowania i rozwoju terenów inwestycyjnych pod działalność przemysłowo-usługową;

- zintegrowane inwestycje terytorialne oraz zintegrowane porozumienia terytorialne;

- geoankieta do zbierania dokładnych informacji o wszystkich inwestycjach realizowanych i planowanych na terenie całego województwa;

- długoletnia prognoza finansowa;

(na poziomie lokalnym):

- koncepcja rozwoju gminy - społeczna akceptacja celów rozwoju;

- obowiązkowy Miejscowy plan ogólny dla dużych miast / lub wzmocnione SUiKZP jako dokument typu regulacyjnego z podziałem na trzy podstawowe klasy gruntów w celu monitorowania zmian: 1) obszarów do urbanizacji, rozwoju, 2) obszarów z możliwością rozwoju, urbanizacji, przekształceń, 3) obszarów nieprzeznaczonych do urbanizacji/rozwoju - spójne z podziałem klasyfikacji HILUCS (która dotyczy istniejącego zagospodarowania terenu/przestrzennego, jak i planowanego zagospodarowania przestrzennego).

Przy nowelizacji prawa powinno znieść się przepis uchwalania istniejących uwarunkowań.

\section{KONKLUZJA}

Zaprezentowane wyżej odpowiedzi na pytania badawcze wymagają dalszych dyskusji. Autorka po zapoznaniu się z udostępnionymi modelami: 1) „Planowanie przestrzenne w zintegrowanym systemie polityki rozwoju" poziomu regionalnego - J. Pietruszewskiego, 2) „Zintegrowane planowanie” poziomu lokalnego - M. Świetlika (koordynatora zespołu ds. komisji planowania przestrzennego warszawskiego TUP), 3) projektem ustawy o zmianie ustawy o zasadach polityki rozwoju z 29 marca 2019 roku, 4) projektem ustawy o zmianie ustawy Prawo geodezyjne i kartograficzne z 15 kwietnia 


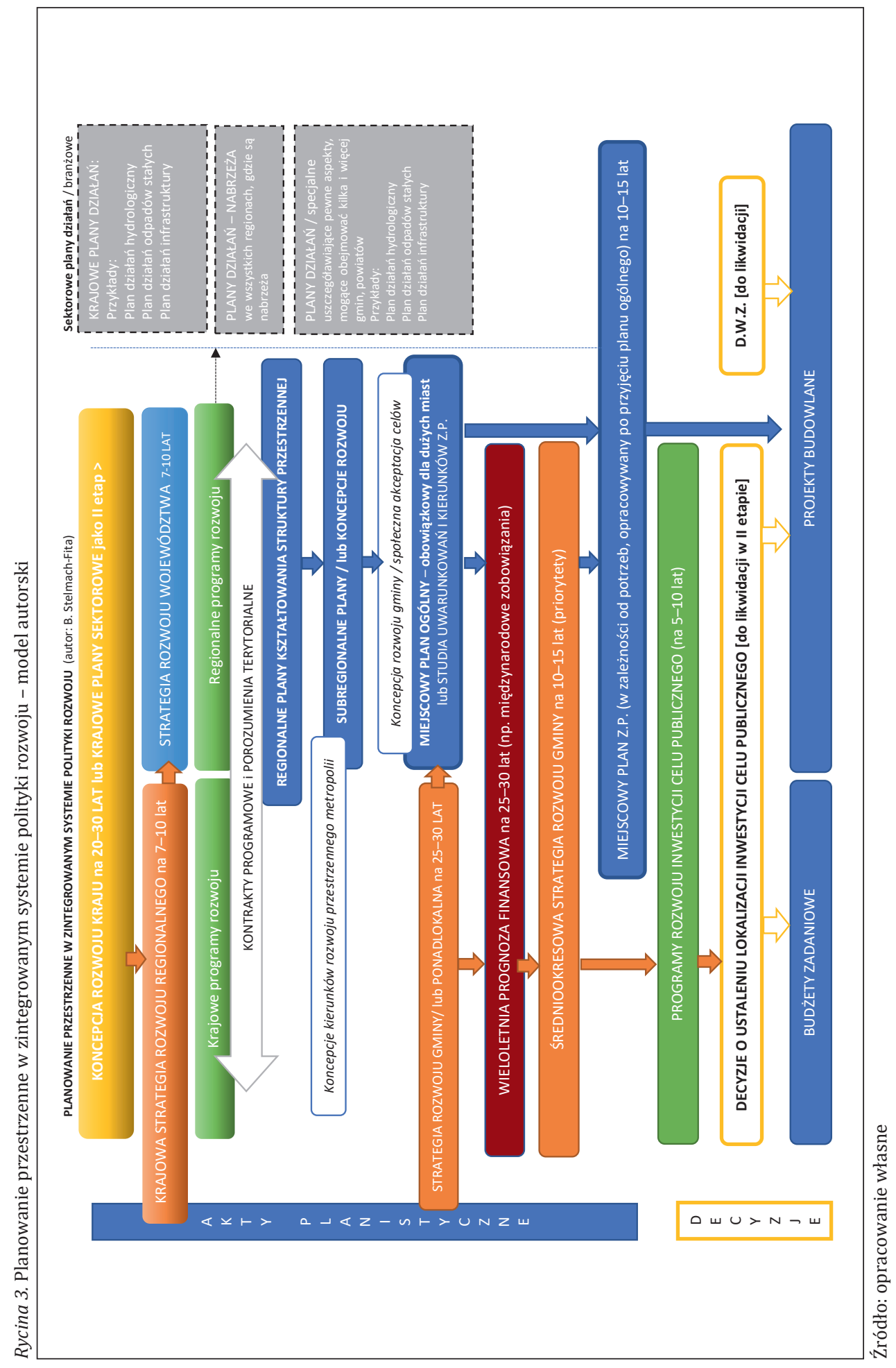


2019 roku, jak również inspirując się dostępnym schematem Land Use w Hiszpanii (The Governance of Land Use, 2019), dokonała próby opisania rekomendacji w postaci autorskiego schematu/modelu - Planowanie przestrzenne w zintegrowanym systemie rozwoju również wymagającego rozwinięcia i dalszych dyskusji.

(Zaznaczone kolorem szarym „sektorowe plany działań” są dokumentami analogicznymi do programów operacyjnych funkcjonujących obecnie w Polsce. Umieszczenie ich obok schematu ma na celu tylko zasygnalizowanie, że wymagają one usystematyzowania i większego zróżnicowania na wzór „sektorowych planów działań” w Hiszpanii).

Rekomenduje się ogólne kierunki zawarte w ww. projektach ustaw, z wyjątkiem kwestii propozycji łączenia planu województwa ze strategią rozwoju województwa. W I etapie reformy rekomenduje się wprowadzenie miejscowego planu ogólnego/ lub wzmocnione SUiKZP i rezygnację z „decyzji o warunkach zabudowy”, w kolejnych etapach, również z decyzji inwestycji celu publicznego oraz z decyzji specjalnych.

\section{Literatura}

References

Agenda terytorialna i reformujący ją Traktat lizboński z 13 grudnia 2017 roku, art. 3 (2019, 7 czerwca). Pozyskano z https://www.espon.eu/tools-maps/regional-typologies

Belof, M. (2013). Teoria a praktyka planowania regionalnego. Doświadczenia polskie w planowaniu przestrzennym po 1998 r. Wrocław: Oficyna Wydawnicza Politechniki Wrocławskiej, 148-150.

BOE (Aencia Estatal Boletín Oficial del Estado) (2019, 9 czerwca). Pozyskano z https://www.boe. es/legislacion/codigos

Contin, A. (2019, 7 czerwca). Prezentacja „Metropolitan landscapes. Resilient articulation of the interface between city, agriculture and nature promoting the quality of dwelling and ensure the human well-being within the metropolis" o projekcie MS [lab] TELLme na 10th IALE World Congress, July 1-5, 2019; Milano. Pozyskano z www.researchgate.net/publication/333371485_IALE19_World_Congress_Landscape_Ecology_MSLab_TELLme_will_organise_the_Symposium_Metropolitan_Landscapes_Resilient_articulation_of_the_interface_ between_city_agriculture_and_nature_promoting_the_qual

Contin, A., Sanna, S. (2019) (2019, 7 czerwca). Training for education, learning and leadership towards a new metropolitan discipline - Metropolitan Architecture: A Ground Project. New typologies and land uses. Pozyskano z ttps://www.researchgate.net/publication/333648735_190207_lecture_TELLme_ContinPOIiS/Ogloszenia_POIiS/Aktualnosci/ KDP_01_-_Katalog_dobrych_praktyk.pdf

Grochowski, M. (2017, 11 stycznia). Regionalne obserwatoria terytorialne jako instrument monitorowania regionalnego, warsztaty w Białobrzegach, 20-21 maja 2011 roku. Pozyskano z http://yadda.icm.edu.pl/yadda/element/bwmeta1.element.desklight-970b-40b1-8f65-4313-a77a-ad10f26196ff/c/msr_7_grochowski.pdf

Guranowska-Gruszecka, K., Łaskarzewska, M. (2018). Węzły miasta. Warszawa: Fundacja Wydziału Architektury Politechniki Warszawskiej, 10-14.

Izdebski, H. (2010). Dwadzieścia lat samorządu terytorialnego - potrzeba rozwiązywania problemu Metropolii. W: A. Lutrzykowski, R. Gawłowski (red.). Metropolie. Wyzwanie polskiej polityki miejskiej. Toruń: Wydawnictwo Adam Marszałek, 15-23.

Janas, K., Jarczewski, W. (red.) (2017) (2019, 20 czerwca). Raport o stanie polskich miast. Zarzqdzanie i współpraca w miejskich obszarach funkcjonalnych. Kraków: Obserwatorium Polityki Miejskiej. Instytut Rozwoju Miast. Pozyskano z http://obserwatorium.miasta.pl/wp-content/uploads/2017/10/OPM_IRM_Zarz\%C4\%85dzanie-i-wsp\%C3\%B3\%C5\%82 praca-w-miejskich-obszarach-funkcjonalnych_Raport-o-stanie-polskich-miast_2017.pdf

Kaczmarek, T. (2005). Struktury terytorialno-administracyjne i ich reformy w krajach europejskich. Poznań: Wydawnictwo Naukowe Uniwersytetu Adama Mickiewicza. 
Kaczmarek, T., Mikuła, T. (2007). Ustroje terytorialno-administracyjne obszarów metropolitalnych w Europie. Poznań: Bogucki Wydawnictwo Naukowe.

Kodeks urbanistyczno-budowlany. Wersja z 30 września 2016 r. - konsultacje publiczne (2016) (2019, 20 czerwca). Warszawa: Ministerstwo Infrastruktury i Budownictwa. Pozyskano z http://mib.gov.pl/files/ 0/1797410/projektKUB.pdf

Kolipiński B. (2012, 20 września). Pozyskano z www.mrr.gov.pl/rozwoj_regionalny/Ewaluacja_ i_analizy/Raporty_o_rozwoju/Raporty_krajowe/Docomenst/Ekspertyza_Lad_przestrzenny_w_Polsce_stan_i_problemy_20072011.pdf

Koncepcja kierunków rozwoju przestrzennego metropolii Poznań - projekt (2015, luty). Poznań: Centrum Badań Metropolitalnych Uniwersytetu im. Adama Mickiewicza. Pozyskano z https://drive.google.com/file/d/0B8ZDvm0g4d_VeUtzQThDeFQ1cVk/view

Lackowska, M. (2009). Zarzq̨dzanie obszarami metropolitalnymi w Polsce: między dobrowolnościq a imperatywem. Warszawa: Wydawnictwa Uniwersytetu Warszawskiego.

Markowski, T. (2011). Terytorialny wymiar zintegrowanej polityki rozwoju - oczekiwania i wyzwania wobec planowania i systemu instytucjonalnego. Prezentacja na posiedzeniu plenarnym KPZK w Warszawie w dniu 13 września 2011 r.

Markowski, T. (2017) (2019, 20 czerwca). Prognozy społeczno-gospodarcze w aktach planowania przestrzennego jako próba racjonalizacji popytu na tereny rozwojowe. Pozyskano z https://profesjonalista.net/v2/wordpress/?p=13708

Mikuła, Ł., Kaczmarek, T. (red.) (2016). Integracja planowania przestrzennego $w$ Metropolii Poznań - problemy, metody, osiagnięcia. Poznań: Biblioteka Aglomeracji Poznańskiej.

Projekt ustawy o zmianie ustawy Prawo geodezyjne i kartograficzne i innych ustaw z 15 kwietnia $2019 \mathrm{r}$.

Projekt ustawy o zmianie ustawy o zasadach polityki rozwoju z 29 marca 2019 r.

Rozporządzenie Komisji (UE) nr 1253/2013 z dnia 21 października 2013 r. zmieniające rozporządzenie (UE) nr 189/2010 w sprawie wykonania dyrektywy 2007/2/WE Parlamentu Europejskiego i Rady w zakresie interoperacyjności zbiorów i usług danych przestrzennych.

Specyfikacja danych Land Use (2013). D2.8.III.4 Data Specification on Land Use - Draft Guidelines. Pozyskano z http://inspire.ec.europa.eu/documents/Data_Specifications/INSPIRE_ Data Specification_LU_v3.0.pdf

Stelmach-Fita, B., Pękalska, M., Bartoszczuk, P. (2018). Usługi informacyjne w zakresie nowego zintegrowanego planowania jako czynnik determinujący rozwój przedsiębiorstw. Prace Komisji Geografii Przemysłu Polskiego Towarzystwa Geograficznego, 32(3), 216-236.

Stelmach-Fita, B., Pękalska, M., Bartoszczuk, P. (2017). Monitorowanie oraz udostępnianie informacji o zjawiskach społeczno-gospodarczych i przestrzennych w Polsce. Prace Komisji Geografii Przemysłu Polskiego Towarzystwa Geograficznego, 31(3), 167-184.

Stelmach-Fita, B., Brodowicz, D. (2017). Baza wiedzy o regionie i jej rola w rozwoju terytorium. Biuletyn KPZK PAN, 268, 186-208.

The Governance of Land Use (2019, 9 czerwca). COUNTRY FACT SHEET SPAIN. Pozyskano z https://www.oecd.org/regional/regional-policy/land-use-Spain.pdf

Zaucha, J. (2012) (2019, 9 czerwca). Synteza aktualnego stanu wiedzy dot. rozwoju sustensywnego i spójności terytorialnej w planowaniu przestrzennym (Analiza dokumentów UE BSR i polskich). Sopot: Instytut Rozwoju. Institute for Development Working Papers. Pozyskano z http://instytut-rozwoju.org/WP/IR_WP_5.pdf

Vergas-Tetmajer, A. (2017). Miasta w politykach UE i świadomości społecznej. W: T. Majda, I. Mironowicz (red.). Manifesty urbanistyczne w poszukiwaniu współczesnego modelu miasta. Biblioteka Urbanisty, 143.

Zuziak, Z.K. (2018). Węzły miejskości a modele przestrzenne struktur miejskich. Z notatek nt. synergii w urbanistycznych konstrukcjach śródmieść. Budownictwo i Architektura, 17(3), 107-129.

Beata Stelmach-Fita, dr inż., adiunkt, absolwentka Wydziału Architektury Politechniki Warszawskiej, doktor nauk technicznych $w$ dyscyplinie architektura i urbanistyka. Zainteresowania badawcze dotyczą geoinformacji w temacie zagospodarowanie przestrzenne oraz upowszechniania technologii GIS do potrzeb zarządzania przestrzenią miejską. Jest autorką projektów budynków użyteczności publicznej, mieszkalnych, opracowań planistycznych. Posiada doświadczenie $w$ pracy w jednostkach samorządu terytorialnego ( $w$ tym wdrażanie GIS dla potrzeb Urzędu M. St. Warszawy) oraz w administracji centralnej. Otrzymała rekomendacje Izby 
Architektów RP do prac w komisjach dotyczących tematu danych przestrzennych zagospodarowanie przestrzenne - 2014 rok.

Beata Stelmach-Fita, PhD, she has graduated from Architecture at the Warsaw University of Technology, doctor of technical sciences in architecture and urbanism. Her research interests include geoinformation in Land Use and dissemination of GIS technology for urban management. She is the author of projects of public and residential buildings, as well as of local spatial development plans. She has experience in local government (including the implementation of GIS for the Warsaw City Hall) and in central government. In 2014 she received the recommendations of the Chamber of Architects for work in the committees on spatial data on Land Use.

ORCID: 0000-0001-7731-8779

\section{Adres/address:}

Uniwersytet Pedagogiczny w Krakowie Instytut Geografii

Katedra Przedsiębiorczości i Gospodarki Przestrzennej

ul. Podchorążych 2, 30-084 Kraków, Polska

e-mail: bfita@up.krakow.pl 